\title{
B.C. Registered Foresters Elect Officers
}

Eric W. Robinson, Forester, i/c Forest Service Ranger School at Green Timbers, was elected President of the Association of British Columbia Foresters at the Fourteenth Annual Meeting held in Kamloops for the first time. It was the first convention held in the year of the one hundred and fiftieth anniversary of the founding of Kamloops.

Mr. Robinson succeeded Thomas G. Wright, Chief Forester, Canadian Forest Products Ltd, who becomes Past-President.

The Vice President is Lawrence A. deGrace, Manager, Industrial Forestry Services Ltd., Prince George.

The other member re-elected to Council was John S. Stokes, i/c Management, B. C. Forest Service, Victoria.

Newly-elected Councillors are: Irving K. Barber, Manager, Forest Operations Division, MacMillan, Bloedel \& Powell River Ltd.; Raymond R. Lejeune, Officer-in-charge, Forest Entomology \& Pathology Laboratory, Canada Dept. of Forestry, Victoria; Frank G. Rainsford, Consulting Forester, Victoria; and Ian H. Schiedel, Industrial Forester, Haney.

F. M. Knapp, Faculty of Forestry, U.B.C. was re-appointed Registrar.

\section{SOCIETy of AMERICAN Foresters Holds RefERENDUM ON WILDERNESS ESTABLISHMENT}

By a significant majority, members of the Society of American Foresters in a mail referendum on December 2 expressed their approval of the present method of establishing wilderness areas on federal lands, and their disapproval of a proposed wilderness preservation system by act of Congress.

A total of 4,235 members approved the following propostion:

"Wilderness areas should continue to be established by executive action of the Secretaries of the Federal Departments that are administratively responsible for the establishment of present and potential areas suitable for wilderness preservation." sition:

Less than 29 percent $(1,693)$ of the voters approved the alternate propo-

"Wilderness areas as now established should be included in a wilderness preservation system by act of Congress with specifications as to permitted uses and with provision for additions, deletions, and the designation of new areas." Background

About four decades ago foresters in the U.S. Forest Service developed the concept of wilderness land-management. Over the years, under policies adopted by the Service, certain national forest lands have been set aside as wilderness areas.

Within wilderness areas no permanent roads may be built, no mechanized equipment is permitted, and no commercial logging is carried on. Resorts, summer homes, organization camps, and similar uses are excluded. In short, wilderness areas are nuaintained in as near their natural state as is possible.

Because of changing conditions in national forest management and administration, from time to time the boundaries of certain wilderness areas have been modified. There have been some deletions in acreage; in total, however, the number of acres has increased. 
Now designated as wilderness-type areas are 83 separate tracts, about 8 percent of the 186 million acres of the national forest system. They are located on parts of 73 national forests in 14 states. Their combined area is 14.5 million acres.

During the past decade a number of citizens and organizations concerned with natural resources have advocated the creation of a wilderness preservation system by act of Congress. This proposed legislation would provide for three specific actions, among others. It would (1) include presently established wilderness areas in a wilderness preservation system; (2) specify the manner in which new wilderness areas or modifications of existing areas should be accomplished; and (3) specify the uses to be permitted within such areas.

Stated briefly, proponents of the legislation want the Congress to adopt a national policy on wilderness areas, and to specify procedures for their establishment, modification, and permitted uses. Under the proposed legislation, certain determinations with respect to presently established wilderness areas, such as the final modification of boundaries and the elimination of portions, would be removed from the discretion and authority of those responsible for their administration. Instead, consideration by Congress would be required.

Opponents of the legislation object to the statutory fixing of boundaries and the impossibility of withdrawals, except following Congressional review. Increasing demand by an expanding population for forest products and services should be correlated, they say, with such demand and with the acreage of forest available in each region. Many view the proposed wilderness preservation system as a "locking up" of vast areas for limited use, inconsistent with multiple-use management for the development of all renewable natural resources.

\section{An Explanation of National Parks Policy on THE EXPloitation OF Forest REsOuRCES ${ }^{2}$}

To most of us a park is simply a place where we enjoy nature and the outdoors and we are concerned only with the benefits we can derive from it. From this standpoint it matters little whether the park is a national, provincial or municipal park, or some other type of area. It is this essentially practical approach which often leads to uncertainty as to what constitutes a national park, and confusion as to standards of national calibre and quality, as compared with the requirements for local parks and other outdoor recreation facilities. In addition, large areas of undeveloped land are readily visible to casual visitors to our national parks because roads and trails have been developed in the parks for just that purpose-to bring large areas of land in its natural condition within easy reach of the people of Canada. To the forester this fact, combined with the impressive figure of 29,000 square miles comprising the parks, is apt to obscure the more realistic view that unexploited forest lands in the national parks represent only a fraction of one per cent of the accessible commercial forest lands in Canada.

\footnotetext{
1 This comprehensive explanation of the policy of Canada's National Parks has been given to the C.I.F. by the Hon. Mr. Walter Dinsdale, Minister of Northern Affairs and National Resources, Ottawa, Ont. It supplements his letter of Nov. 7, 1961, to J. J. E. Dosne acknopledging the C.I.F. resolution on National Parks policy passed at the 1961 Annual Meeting.
} 